\title{
DIFFERENT ATTITUDES OF THE HOLY VIRGIN MARY IN COPTIC ART
}

\author{
DR. SHERIN SADEK EL-GENDI*
}

\begin{abstract}
In this paper, my focus will be on the different attitudes of the Holy Virgin Mary which appear in the decoration of several Coptic artistic collections conserved and displayed now in the Coptic Museum in Cairo and in the other international archeological museums abroad. This study deals also with some of the Mariological scenes decorating the interior walls of many Coptic monasteries and churches in Old Cairo, Wadi Natrun, Sohag and the Red Sea. Moreover, the present study will describe and analyze some precious examples of Coptic stone work, woodwork, metal objects, ivory panels, manuscripts, icons and wall paintings in order to know more details about the various depictions of the Holy Virgin Mary and her figures in Coptic art.
\end{abstract}

-Associate Professor of Coptic and Islamic art and archaeology in the Tourist Guidance Section (French Department) in the Faculty of Arts/Ain Shams University. Cairo (EGYPT). 
Both in Christianity and Quran, the Holy Virgin Mary is mentioned several times. She is the only woman having a chapter bearing her name in Quran (Sourat Mariam). In this paper, my focus will be on the different attitudes of the Holy Virgin Mary which appear in the decoration of several Coptic artistic collections conserved and displayed in the Coptic Museum in Cairo and in the other international archeological museums abroad. This study deals also with the Mariological scenes decorating the interior walls of some Coptic monasteries and churches in Old Cairo, Wadi Natrun, Sohag and the Red Sea. The present study will describe and analyze some precious examples of Coptic stone work, woodwork, metal objects, ivory panels, manuscripts, icons and wall paintings in order to know more details about the life of the Holy Virgin Mary and her different figures in Coptic art.

Before starting to show the different attitudes of the Virgin Mary in Coptic art, it is important to describe the icon ${ }^{1}$ depicting her Birth (PI. I). Inside a room with arched doorway leading to another room, there is a light at the background of the scene. Anna the Virgin's mother is lying on an oval-shaped bed under the canopy. Reclining against a brown cushion, she is holding the child with her hands. Her white maphorion and her green tunic cover her feet. Her arms crossed before her chest, the Holy Virgin Mary is on her mother lap and she wears a golden tunic and maphorion. Carrying a bowl in hands, a maid wearing a blue green tunic bends her hands towards the Child and her mother. With gray hair, beard and moustache, Joachim the Virgin's father is sitting in to the right side on a golden bench. Wearing a green tunic and a red pallium, he holds a book in his hands. Inscriptions near Mary's head and at the top of the icon confirm the birth of the Mother of God. With its external red border, this icon dates back to the $18^{\text {th }}$ century A. D.

\footnotetext{
${ }^{1} \mathrm{~N}^{\circ}$ 6994. Dimensions: $26,7 \times 35,3 \times 2,6$. Presented by GABRIEL BEY AWAD NAWAR on the $9^{\text {th }}$ of May 1941. The Icons. Catalogue général du musée copte, Published by P. VAN MoORSEL, MAT. IMMERZEEL and L. LANGEN, Supreme Council of Antiquities Press, Cairo, 1991, 81$82, \mathrm{n}^{\circ} 89, \mathrm{Pl} .22 / \mathrm{b}$.
} 
One of the most interesting and complete icons conserved in the Hanging Church of the Holy Virgin Mary in Old Cairo is showing different episodes from her life ${ }^{2}$ especially her presentation in the temple (PI. II). On the following important icon, the Holy Virgin Mary is holding her Infant in the Middle and she is surrounded by other scenes like her miracle to one of her disciples named Mathias in the right uppermost side of the icon. Her parents Hanna and Joachim are praying in order to have a child, the Annunciation, Zacharias and the Visitation to Elisabeth, Joseph the Carpenter and Salome, the Nativity, the Adoration of the Magi, the Flight into Egypt, the Dormition and the Assumption of her body. The icon, painted by the two famous artists John the Armenian and Ibrahim al-Nasikh, is dating from 1760 A. D. It has a recent wooden frame decorated with a band of Coptic inscriptions.

Discovered in Akhmim, a wooden Tondo ${ }^{3}$ or a medallionportrait preserved in the Coptic Museum in Cairo is depicting the Holy Virgin Mary in bust on a yellow back ground (PI. III). It is one of her rare early figures without Jesus the Infant. Her purple maphorion is decorated with a small cross in a black rectangle on the forehead. She has a upward-gazing eyes, wide nose and pursed lips. Her face is flanked by Greek inscription read as follow: $\mathrm{H}$ АГIA MAPIA (Saint Mary). According to Z. SKALOVA and G. GABRA, the technique of this object is the tempera ${ }^{4}$ but according to what is written in The Icons. Catalogue général du musée copte, this is an encaustic painting ${ }^{5}$. Dating from the $6^{\text {th }}-7^{\text {th }}$ century A. D.,

${ }^{2}$ The Escape to Egypt according to Coptic tradition, $1^{\text {st }}$ ed., Photos NABIL Selim ATALla, Lehnert and Landrock Publisher, Cairo, 1993, 37; Coptic Icons, $1^{\text {st }}$ ed., I, Lehnert and Landrock Publisher, Cairo, 1998, 73-76; MAGDI GUIRGUIS, Yuhanna al-armānī wa ayqūnātuh al-qibtīya. Fanān fì al-qāhira al-qutmānīya, the Supreme Council of Culture Publication, Cairo, 2008, 197.

${ }^{3} \mathrm{~N}^{\circ}$ 9104. Dimensions: $8,5 \times 2,0 \times 0,1$. Catalogue, 13, pl. 2/c; Z. SKALOVA and G. GABRA, Icons of the Nile Valley, Egyptian International Publishing Company-Longman, Cairo, 2006, $167, \mathrm{n}^{\circ} \mathrm{A}$.

${ }^{4}$ Z. SKALOVA and G. GABRA, Icons, $167, \mathrm{n}^{\circ} \mathrm{A}$.

${ }^{5}$ Catalogue. 13, pl. 2/c. 
this small wooden circular panel has holder in its lower edge perhaps to be fixed on to a liturgical stick. What's more, two small holes are visible to the left and the right sides of the Virgin.

In the Annunciation scene ${ }^{6}$ decorating the southern semi dome of the khurus inside the archeological church of the Holy Virgin Mary in the Syrians Monastery in Wadi Natrun, the archangel Gabriel is coming suddenly to the Holy Virgin Mary while she was inside the temple and tells her as written in Coptic:

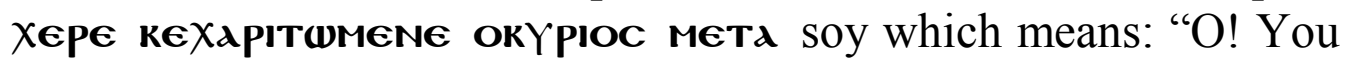
full of grace the Lord is with you"7. The Virgin is surprised from his arrival. $\mathrm{He}$ is raising his right hand to greet her. A bird symbolizing the Holy Spirit is coming down from the blue sky decorated by small white stars. The left wing of the archangel is dividing the semi dome into two equal parts. The names of the Holy Virgin and the archangel are written in both Syriac and Coptic.

\section{arıa Mapld (Saint Mary)}

дрХндггедОс гдпрінд (the archangel Gabriel)

The same scene is also decorating one Coptic manuscript ${ }^{8}$ discovered in al-Hamuli at Fayoum and conserved in the Pierpont Morgan Library in New York city in the United states of America (PI. IV). This manuscript dates back to 913 A. D. This biblical topic is also decorating other several Coptic icons especially this one displayed in the Coptic Museum in Cairo ${ }^{9}$. In this icon dating from

\footnotetext{
${ }^{6}$ Illustrations from Coptic manuscripts, $\mathrm{I}^{\text {st }}$ ed., Lehnert and Landrock Publisher, Cairo, 2000.

7 Lc. $1: 28$; J. LeroY, Les peintures des couvents du Ouadi Natroun, publiées avec la collaboration de B. Lentheric, P. H. LAFERriere, H. STUder, E. RAVAULT, B. PSIROUKIS et J. F. GoUT, MIFAO 101, Le Caire, 1982, 67.

8 M597. Height: 33 cm. Width: 25,5 cm. M. Cramer, Koptische Buchmalerei; Illuminationen in Manuskripten des christlich-koptischen Ägypten vom 4. bis 19. Jahrhundert, Aurel Bongers, Recklinghausen, 1964; J. Leroy, Les manuscrits coptes et coptes-arabes illustrés, Librairie Orientaliste Paul Geuthner, Paris, 1974, 103, pl. 35, B; L. DEPUYDT, Catalogue of Coptic Manuscripts in the Pierpont Morgan Library. Album of Photographic Plates, Photographed by DAVID A. LogGIE, Uitgeverij Peeters, Leuven, 1993; Coptic Icons, II, 98; Coptic manuscripts, 40 .

${ }^{9} \mathrm{~N}^{\circ}$ 4875. Dimensions: 43,5 x 58,8 x 1,9 cm. Painted on linen and fixed to a panel. Presented by Nicola Kyrodos. Catalogue, 99 , n 109, pl. 27/a.
} 
the $17^{\text {th }}$ century A. D., we see the small heads of the human figures compared with their bodies. Moreover, they have slightly curved eyebrows, small eyes, straight noses and mouths. The Annunciation scene decorates also a small damaged wooden pane $1^{10}$ conserved in the Musée du Louvre in Paris. Dating from the $5^{\text {th }}$ century A. D., it is considered to be the most ancient annunciation discovered till now. This time, the Holy Virgin Mary is sitting and seen from profile. We Remarque the absence of the archangel Gabriel whose leg is still visible in the lower corner of the panel perhaps because it is damaged. The same Event is quite similarly mentioned in Quran ${ }^{11}$. According to Quran, the Christ is the only Prophet whose birth was a miracle.

${ }^{10} \mathrm{~N}^{\circ}$. E 17118. Dimensions: 28.5 x $14.2 \times 2$. M. VASSILAKI, Mother of God. Representations of the Virgin in Byzantine Art, Skira, Athens, 2000, 270-271, $\mathrm{n}^{\circ} 6$.

"إنما المسيح عيسى بن مريم رسول الله وكلمته ألقاها إلى مـــريم وروح منــهـ، (Jesus, the Son of Mary, the Apostle of God, is simply His Word and Edict which He authoritatively "إذ قالت الملائكة يا مريم

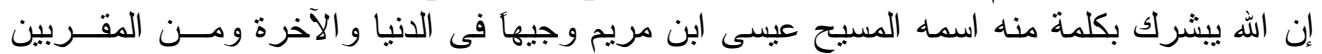
ويكلم الناس فى المهد وكهال ومن الصالحين قالت أنى يكون لى ولد ولم يمسنسى بشر قال كذلك الله

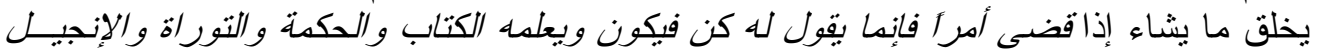

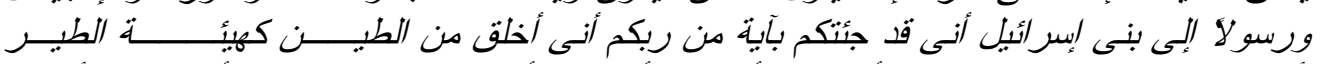

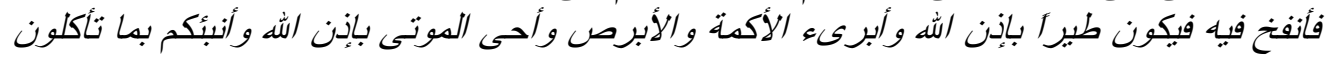
(And for once did the angels say to Mary: O Mary here we relate to you a divine edict: God intimates to you the announcement of a happy event, the arrival of a male child the product of a word from him, designated the Messiah Jesus, son of Mary, who shall be distinguished here and hereafter and of those nearest to God. He shall speak to people in his cradle in infancy and manhood, and he shall be one of those whose deeds are imprinted with wisdom and piety. She, Mary, said: How I have a son O God my Creator when no man has touched me? She was told: Thus does God Create what He will; when He decrees a thing He only says "Be" and it is. He shall teach him the Book of Knowledge and wisdom and He shall teach him the Torah and the Gospel. And he shall be an Apostle to the children of Israel conveying acts of miraculous nature serving to demonstrate his delegated divine power and authority to influence their conduct and their actions; he shall be instructed to say to them; I have brought you an outward and visible sign of an inward and spiritual grace. I shall create for you from clay the figure of a bird and inspirit it and there it shall be a living bird by God's command; I shall restore the sight of him who is congenitally blind and heal the leper and with delegated divine authority shall I raise the dead by God's command. I shall also inform you of what you eat and of what you store in reserve in your homes. This should be enough divine evidence to bring you to acknowledge= 
This unique Coptic annunciation scene ${ }^{12}$ which is executed now in the main church dedicated to the Holy Virgin Mary in the monastery of the Syrians at Wadi Natrun is a rare masterpiece of Coptic art in medieval times ${ }^{13}$ (PI. V). For the first and the last time, the Holy Virgin Mary with the Archangel Gabriel are standing together but surrounded by four prophets of the Old Testament: Moses, Daniel, Isaiah and Ezekiel. Moses and Daniel flank the Virgin and the archangel holding his long cross-staff is surrounded by Isaiah and Ezekiel. Each one of them is holding one opened scroll in which is written his prophecy in bohairic Coptic ${ }^{14}$. Moses text ${ }^{15}$ is in relation with the common title of the Holy Virgin Mary Theotokos in the orthodox hymns which is "the Burning Bush". Moses and Ezekiel are wearing red tunics and bluish pallia. Isaiah wears a beige tunic with red pallium. Daniel is seen with Phrygian clothes consisting of a short tunic and peaked cap. All human figures are haloed and standing in frontal attitude or from three quarters. A small censor with blue flame is put on a small column which appears below in the middle part of the scene. In the uppermost part of the background of the scene, the city of Nazareth is depicted in details with its churches, towers, houses and gardens. Dating this important scene, discovered in 1991 in one of the layers of the western semi dome covering the narthex of the church, was and is till now a matter of controversy among art historians,

$=$ the truth of my mission if indeed your hearts have been impressed with the image of religious and spiritual virtues). The Women, 171; the Family of Umran, 45-49.

12 Coptic Art. I. Wall Paintings, Text and Photos by NABIL SElim ATALla, Lehnert and Landrock Publisher, Cairo, 1993, 155-158; Coptic Icons, I, 18-19; G. GABRA, Coptic Monasteries. Egypt's Monastic Art and Architecture, With a Historical Overview by T. VIVIAN, AUC Press, Cairo-New York, 2002, 53, pls. 3.8-3.9; Z. SKALOVA and G. GABRA, Icons, 117, fig. III. 41.

${ }^{13}$ G. GABRA, Monasteries, 53-54.

${ }^{14}$ Isaiah text is "Behold, a Virgin shall conceive, and bear a son, and shall call his name Emmanuel". Is. 7:14. Ezekiel text is: "Then said the Lord unto me: this gate shall be shut and no man shall enter in by it save the Lord, the God of Israel". Ez. 44:2. Daniel text is: "I saw a stone cut out from the mountain without being touched by hands". Dn. 2: 34.

15 "I saw the bush while the fire was blazing in it, without being consumed". Ex. 3:2. 
archeologists and so many other Coptic scholars. It may date from the $7^{\text {th }}$ to the $13^{\text {th }}$ century A. D.

Although it is partially damaged, the scene of the Visitation of the Holy Virgin Mary to her cousin Elisabeth ${ }^{16}$ is visible also today on the southern wall of the central nave in the main church dedicated to the Holy Virgin Mary in the Baramous Monastery in Wadi Natrun. Both saints are seen standing very close to each other.

Painted on a panel, in the Nativity icon of Saint John Baptist $^{17}$, the Holy Virgin Mary is depicted with her cousin Elisabeth and Zacharias under two arches supported by pillars having abacus. Elisabeth is lying in the middle on an oval-shaped bed under a baldachin with a red curtain. Above her head, a small white-outlined halo is visible. Her hands are crossed before her chest. She wears a light brown maphorion and a blue tunic. Haloed and crowned, Zacharias is sitting to the left side on a throne in front of a baldachin with a red curtain. His hair, beard and moustache are colored in grey. A writing-tablet is seen in his right hand and a feather in the other one. His white tunic with long sleeves is covered with a second red one with short sleeves. In front of the bed, two women are kneeling and washing the child whose head is haloed with white and red outlines. The woman to the left side who wears a light-brown tunic holds a towel, the second women having a grey maphorion and a red tunic takes the child out of the basin including water. One of the two women may be the Holy Virgin Mary and the other may be a slave. Dating from the $18^{\text {th }}$ century A. D., the border of the icon is colored in red. The Greek inscriptions of this icon are translated as follow: The birth of the forerunner (at the top), Zacharias (over his head), Elisabeth (above her head) and John (over the child's halo).

In the Nativity scene decorating the southern semi dome of the khurus in the main church of in the Syrians monastery in Wadi

${ }^{16}$ G. GABRA, Monasteries, 41, pl. 1.3.

${ }^{17} N^{\circ} 6997$. Dimensions: $26,6 \times 35,4 \times 1,6$. Presented on the $9^{\text {th }}$ of May 1941 by Gabriel Bey Awad Nawar. Catalogue, 32, n 90, pl. J 1. 
Natrun, the Holy Virgin Mary is lying and Jesus Christ the Infant is depicted beside her in the crib (PI. VI). There are surrounded by the angels, the shepherds and the three wise men holding their gifts. Below, Saint Joseph the Carpenter appears and his name is written in both Coptic and Syriac languages. They are surrounded by winged angels seen in the upper part of the scene. Below, shepherds are depicted with their animals. The following verse "Glory to the Lord in High, peace to be on the earth and goodwill among the people" $^{18}$ usually appears in such a scene. This decorative scene appears also in the decoration of many different Coptic icons.

In the decoration of one of the precious icons in the Coptic Museum in Cairo, the Adoration of Shepherds scene is depicted in one section and the Annunciation scene is in the other part ${ }^{19}$ (PI. VII). Sitting behind a table covered by a red napkin, the Virgin Mary is looking to the archangel Gabriel who is approaching from the left side raising his left hand in the gesture of greeting. An opened book is put on the table in front of her. In the Adoration scene, the child lying on a white cloth is in the crib with white wrappings. He is surrounded by his mother and Saint Joseph the Carpenter whose hands are in the praying gesture. Having similar features, one of the two shepherds depicted is kneeling and stretching his hands forward. The other one stretches his right hand to Jesus the Child. The two parts of the icons are richly decorated with a wooden and metallic frame with green, blue and red floral designs. The western artistic style influence is evident in the icon which dates back to the $18^{\text {th }}$ century A. D.

It seems also that the Copts were influenced by the Ancient Egyptians especially in the decoration of some Coptic wall paintings. One of the most important decorative topics is a wall painting showing the Holy Virgin Mary suckling Jesus Christ the Infant seen on her lap. To well understand the background of this

${ }^{18}$ Lc. 2:14.

${ }^{19} \mathrm{~N}^{\circ} 3535$. Dimensions: 7,7 x 10 x 1,2 cm. Catalogue, 135-136, n ${ }^{\circ} 152$, pl. 41/a. 
representation, we must turn back to Ancient Egypt because such a scene recalls this one depicting the famous Ancient Egyptian goddess Isis suckling her savior son the god Horus ${ }^{20}$. This topic depicting the Nursing Virgin feeding her son can be seen now in the wall painting discovered by the British archeologist E. QUIBELL in the monastery of saint Jeremiah at Saqqara ${ }^{21}$ by the beginning of the $20^{\text {th }}$ century (PI. VIII). This wall painting, dating from the sixth century A. D. and conserved in the Coptic Museum in Cairo, is similar to another encaustic example conserved now on a half column in the khurus of the main church of the Holy Virgin Mary within the Syrians Monastery in Wadi Natrun ${ }^{22}$. The Virgin is setting and wearing a blue tunic with clavi and bluish-green maphorion decorated with small crosses. In fact, the artistic style of the execution shows how skillful the artist was. Dating from the second half of the seventh century A. D., this wall painting was discovered, in 1996, by K. C. INNEMEE the director of the scientific mission excavating the site now. The third example of the Virgin in lactation exists in the Red Monastery of Saint Pishoi in Sohag which is being renovated now by the scientific members of the American mission under the direction of ElisABETH BOLMAN. The same topic is repeated in the decoration of several Coptic icons

${ }^{20}$ L. LANGENER, Isis Lactans-Maria Lactans. Untersuchunngen zur koptischen Ikonographie, Oros Verlag, Altenberge, 1996, 41, 62-82, figs. 1-15; E. S. Bolman, the Coptic Galaktotrophousa as the Medicine of Immortality, Ph. D. Dissertation, Bryn Mawr College, 1997; L. VAN ROMPAY and K. C. INNEMÉE, "La présence des syriens dans le Wadi alNatrun", Parole de l'Orient, XXIII, Paris (1998), 171, n B. 3, fig. 3; Coptic manuscripts, 38; Z. SKALOVA and G. GABRA, Icons, 21, fig. 12.

21 J. QuiBELL, Excavations at Saqqara, 1906-1909, Service of Egyptian Antiquities: Institut français d'archéologie orientale, Cairo, (1908-1909, 1912); M.-R. DEBERGH, "Dayr Apa Jeremiah: Paintings", in : A. S. ATIYA, (ED.), CoptEnc., III, Macmillan Publishing Company, New York (1991), 777-779; Coptic Art, I, 18-19.

${ }^{22}$ P. VAN MOORSEL, "La grande annonciation de Deir es-Sourian”, BIFAO 95, Le Caire (1995), 517-537; K. INNEMÉE, "the Iconographical Program of Paintings in the Church of al-Adra in Deir al-Sourian: Some Preliminary Observations", SKCO, III, Wiesbaden (1998), 143-149; L. VAn Rompay and K. C. InNemÉe, Présence, 171, n B. 3, fig. 3; K. InNemée, "New Discoveriesat deir al-Sourian, Wadi al-Natrun", SKCO, IV/1, Wiesbaden (1999), 213-219; G. GABRA, Monasteries, 52, pl. 3.4. 
hanging in different Coptic churches and monasteries. The same subject is also the decoration of one the most important Coptic papyrus $^{23}$ which dates to $897 \mathrm{~A}$. D. and which is conserved in the Pierpont Morgan Library in New York. It was discovered in 1910 in a cistern in al-Hamuli very close to Fayoum. The Virgin Lactans is a common decorative topic which appears in other several Coptic manuscripts ${ }^{24}$ and icons ${ }^{25}$.

Dating from the $18^{\text {th }}$ century A. D., an icon with unknown provenance and conserved in the Coptic Museum in Cairo shows the Flight of the Holy Family into $\operatorname{Egypt}^{26}$ (PI. IX). Beard, Saint Joseph the Carpenter is walking and holding the saddle of the animal in one hand and a tau-staff in the other. In the same time, he looks backwards at the Holy Virgin Mary. His hair, beard and moustache are colored in white and his feet are sandaled. Having a white tunic under a red pallium, he holds Jesus Christ the Infant on his right shoulder. The Infant has one leg on the front side and one hand on Saint Joseph the Carpenter's head. Barefoot, he looks towards his mother. Wearing a blue tunic and red shoes, the Holy Virgin Mary is on the animal back moving to the right side and she is holding the animal's reins in hands. All human figures are haloed and the Virgin's head is covered with a red maphorion over a bluewhite kerchief. In the background of the scene, the pyramids, some white houses with red roofs and palm trees are executed in a greenbrown landscape. Below, an Arabic inscription is read as follow:

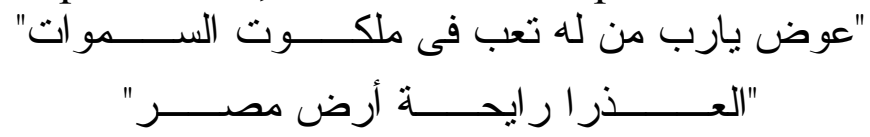

${ }^{23}$ M 574, M 612, $\mathrm{f}^{\circ} 1$ v. Dimensions: 280 x $220 \mathrm{~mm}$. Purchased in 1911. Book of Holy Hermeniae with hymns and so many different liturgical texts. August Company, 72; J. LEROY, Manuscrits, 34, pl. 31.

${ }^{24}$ Coptic Manuscripts, 26; Coptic Icons, II, 98-99.

${ }^{25}$ Coptic Icons, II, 36-37.

${ }^{26}$ Mt. $2: 13-15 ;$ Mt. $2: 15 ;$ Hs. $11: 1 ; \mathrm{N}^{\circ}: 3350$. Dimensions: 77 x 54,7 x $1 \mathrm{~cm}$. Catalogue, 143 , $\mathrm{n}^{\circ} 160$, pl. 42/d; Coptic Icons, I, 78; G. GABRA, Cairo. The Coptic Museum \& Old Churches, with Contributions by A. ALCOCK, Egyptian International Publishing Company Longman, Cairo, 1999, 82, nº 28. 
The translation is: "The Virgin is on her way to Egypt. Lord, remember in the kingdom of Heaven he who toiled". Information regarding the Escape of the Holy family into Egypt is very important to the Coptic Tradition. Such a decorative scene is describing one of the most important events celebrated annually by the Coptic Orthodox Church in Egypt on the $24^{\text {th }}$ of Bachons/the $1^{\text {st }}$ of June. The icon which is painted on linen attached to wood has a yellow outlines and a brown border decorated in the corners by floral patterns.

An important pair of icons placed in an orange wooden frame and displayed shows also the Holy Family to the left and Saint Nicolas to the right ${ }^{27}$. From left to right, the Holy Virgin Mary, Jesus Christ the Infant and Saint Joseph the Carpenter stand on a background with golden color in its upper part and colored in green at its bottom. Their haloes are decorated with punched small rosettes and outlines. The Holy Virgin Mary turns towards her Child and holds a golden book in her right hand. She wears a dark blue-grey tunic with belt and red shoes. Giving his hands to the saints, Jesus the Child who has short brown hair is wearing a golden tunic with a belt and red shoes like his mother. Above his head, a white dove symbolizing the Holy Spirit is coming down from the sky. Beard, Saint Joseph the Carpenter holds a branch of white lilies in his left hand. Wearing a blue-grey tunic, a red pallium and red shoes, he is seen with a brown hair. The icon dating back to the $18^{\text {th }}$ century A. D. is well preserved in the Coptic Museum.

The Holy Virgin Mary appears also holding Jesus the Infant near her bust (PI. X) and she is appointing on his direction. Such an attitude is very common in the decoration of several Coptic icons and wall paintings. The Virgin Hodegetria is also shown between Saint Peter and Saint Roch in the decoration of another icon ${ }^{28}$ (PI. XI). In the background, the artist well executed the brown

${ }^{27} \mathrm{~N}^{\circ} 3419$. Dimensions: 46,3 x 31 x 3,3 cm. Catalogue, 128-129, n 145, pl. 39.

${ }^{28} \mathrm{~N}^{\circ}$ 3862. Dimensions: $37 \times 31,6 \times 1,2 \mathrm{~cm}$. Donated by Pascale on the $5^{\text {th }}$ of May 1933. Catalogue, $133, \mathrm{n}^{\circ} 150, \mathrm{pl}$. 40/b. 
landscape and the golden sky. All saints are seen with half figures and haloes with punched decoration. In the middle, the Holy Virgin Mary is holding her Infant on her left knee by his shoulder with her left hand and she is stretching her other hand to him. She appears with her red maphorion and her black tunic with golden decoration. Blessing by his right hand and holding a globe with a small cross, Jesus the Infant turns his head away from his mother. Having a short brown hair, he wears a grey tunic under a red pallium. With his short curly hair, beard and moustache, the saint who is shown to the left side holds a staff and wears a golden tunic covered by a light brown pallium. Also beard, the other saint is depicted with a long brown hair. In general, the saints have long and thin eyebrows, small noses and mouths. The shadows seen in the faces of the Child and his mother proof how was skillful the painter of this icon dating from the $18^{\text {th }}$ century A. D.

The depiction of the Holy Virgin Mary kissing Jesus Christ the Infant and vis verca is not frequent in Coptic art. It is an icon which is displayed now within the church of abba Iskhiroun alQillini inside the monastery of Saint Macarius the Great in Wadi Natrun. It is a very precious icon because of this uncommon representation for the Virgin in Coptic art.

The Virgin and Jesus the Infant are usually flanked by two winged angels or the two archangels Gabriel and Michael for protection as in the Apse of the central chapel within the archeological church of Saint Anthony the Great in the Red Sea. This topic showing the Mother of God firstly appeared in Alexandria ${ }^{29}$.

Dating from the $6^{\text {th }}-7^{\text {th }}$ century A. D., a niche from the monastery of Saint Apollo at Bawit ${ }^{30}$ is showing the same attitude of the Holy

${ }^{29}$ TH. F. Matheus AND N. Muller, "Isis and Mary in Early Icons”, in: M. VASSELAKI (Ed.), Images of the Mother of God. Perceptions of the Theotokos in Byzantium, Burlington, 2005, 4.

${ }^{30} \mathrm{~N}^{\circ}$ 7118. Dimensions: 220 x $170 \mathrm{~cm}$. Coptic Art, I, 8-9; G. GABRA, Museum, 58-59, n 9; L'art copte en Égypte 2000 ans de christianisme, exposition présentée à l'institut du= 
Virgin Mary. Being one of the most important masterpieces of the Coptic Museum, the niche consists of two zones (PI. XII). In the upper section of the niche, Jesus Christ Pantokrator holding the open holy book and blessing is enthroned within a mandorla supported by angels and surrounded by the four creatures of the apocalypses; the eagle, the bull, the lion and the man. Moreover, the archangels Gabriel and Michael stand to the left and to the right. Their names are written in Coptic on the red band separating the two zones of the niche. In the lower level, the Holy Virgin Mary is enthroned and flanked by the twelve disciples and two local saints. On her lap, she is carrying her Infant holding a scroll. The disciples and saints are beard, standing in frontal attitude and holding books. The features of their faces are not similar and their names are written in Coptic over their heads. Saint Peter holds a key in his hand and Saint Paul is shown with his staff ended with a cross in his right hand. The external border of the niche is decorated with small columns, capitals and Coptic inscriptions. Brilliant colors of the niche are remarkable.

We cannot neglect to mention the rare icon conserved in the Hanging Church of the Holy Virgin Mary in Old Cairo. This icon dating from the $18^{\text {th }}$ century A. D. ${ }^{31}$ is showing her with her Infant and Saint John Baptist at his feet (PI. XIII). Two winged angels are executed in the upper two corners of the icon. The technique used in this icon recalls this one used in the Monaliza painting displayed in the Musée du Louvre in Paris which means that if anyone looks to the saints from any direction, he will feel that they are looking to him. Although, there are few months in age between the Christ and

=monde arabe du 15 mai au 3 septembre et au Musée de l'Éphèse au Cap d'Agde du 30 septembre 2000 au 7 janvier 2001, Institut du monde arabe/Éditions Gallimard, Paris, 2000; G. GABRA, Monasteries, 118-119, pl. 12.3; Z. SKALOVA and G. GABRA, Icons, 20, fig. 11; G. GABRA and M. EATON-KraUss, the Treasures of Coptic Art in the Coptic Museum and Churches of Old Cairo, AUC Press, Cairo-New York, 2006.

${ }^{31}$ Escape to Egypt, 34. 
Saint John Baptist, the first one is shown as a Child but the other one looks like a young man

One of the icons displayed in the Coptic Museum in Cairo shows the Holy Virgin Mary presenting Jesus the Infant to Saint Simon the $\operatorname{Old}^{32}$ (PI. XIV). On a golden background over which a brown baldachin appears between two buildings, Saint Simon the Old holding Jesus the Child, the Holy Virgin Mary, the prophetess Anna and Saint Joseph the Carpenter are represented from right to left. In general, their features are similar which means that they have all small heads, curved eyebrows, small eyes, noses and mouths. Being the longest one, Saint Simon the Old is standing on a platform. Shown with long hair, beard and moustache, his hands are covered by his brown pallium covering his blue tunic and his feet are sandaled. With a cross-halo and a brown hair, the Jesus Infant holds a rolled scroll in his right hand. By his left hand, he touches the right shoulder of Saint Simon the Old. Being barefoot, Jesus is wearing a white tunic and a golden pallium. With a red maphorion, a blue tunic and red shoes, the Holy Virgin Mary is bending her hands towards her Infant. Looking towards Saint Joseph the Carpenter, Anna is pointing upwards by her right hand and she is holding a scroll in her other hand. Saint Joseph the Carpenter holds two white doves in hands. Looking at the Holy Virgin Mary, his hair, beard and moustache are grey. His clothes consist on a blue tunic and a golden pallium. Dating from the beginning of the $18^{\text {th }}$ century A. D., the icon conserves its wooden frame.

In the Coptic Museum in Cairo, the decoration of a niche dating from the $6^{\text {th }}$ century A. D. and discovered at Sakkara shows the Holy Virgin Mary as the one who is wider (PI. XV). The Holy Virgin Mary is raising her hands and standing in frontal attitude and she is surrounded by the disciples. In the upper zone, Jesus-Christ

${ }^{32} N^{\circ}$ 3849. Dimensions: 14,3 x 21,3 x 1,2 cm. Presented by Mrs Hykyrian Pasha. April $29^{\text {th }}$ 1933. Catalogue, 101-102, n¹12, pl. 28/b; Coptic Icons, I, 24-25. 
Pantokrator is seating on his throne, blessing with his right hand and holding the holy book by the other within a mandorla.

The Holy Virgin Mary is also shown as an Orant in the decoration of Coptic stonework and wall paintings. The best example of such depiction is found in the decoration of the western semi dome covering the narthex of the main church of the Virgin in the Syrians monastery in Wadi Natrun ${ }^{33}$. The wall painting is divided into two decorative zones. In the lower one, the Virgin Mary is flanked by the twelve disciples and they are looking up all towards Jesus Christ Pantokrator who appears within a mandorla supported by two winged angels in the upper zone. He holds the holy book in his left hand and he is blessing by the other hand. The moon (mNO) and the sun (mpн) are seen to his right and left sides. The names of the Christ, the sun and the moon are written in Coptic. In addition, some Syriac inscriptions complete the decoration.

In some wall paintings discovered by E. QUIBELL in the monastery of saint Jeremiah at Saqqara, the Holy Virgin Mary is seen while holding Jesus Christ within a clipeus. In the main church of the monastery of Saint Anthony in the Red Sea, the figure of the Holy Virgin Mary is also depicted on the northern side of the eastern wall of the second nave in the archeological church enthroned and holding Jesus Christ Pantokrator within a clipeus $^{34}$ in front of her bust. Both are seen in frontal attitude. The Holy Virgin Mary is wearing a tunica manicata decorated by two potamoi. Her palla is lie-de-vin as well as her maphorion which is decorated with

${ }^{33}$ G. GABRA, Monasteries, 53, pls. 3.6-3.7.

${ }^{34}$ Height: 1,80 m; width: 1,25 m. J. LEROY, "Le programme décoratif de l'église de St. Antoine du désert de la mer rouge", BIFAO, LXXVI, Le Caire (1976), 347-379 ; P. VAN MoORSEL, Les peintures murales du monastère de saint Antoine près de la mer rouge, avec des contributions de P. GROSSMANN, K. C. INNEMEE et P.-H. LAFERRIERE et la collaboration de Ph. Akermann, Abdel-Fatah Nosseir, B. Psiroukis, K. Crena De Iongh et J. Runierse, MIFAO 112, Le Caire, 1995, 142-143, $\mathrm{n}^{\circ} 1.16$ ( $\left.\mathrm{n}^{\circ} 17\right)$, fig. 34, pls. 79-80; G. GABRA, Monasteries, 80, pl. 6.9; E. S. BOLMAN and P. GODEAU (ED.), Monastic Visions: Wall Paintings from the Monastery of St. Antony at the Red Sea, Yale University Press, Cairo, 2002; al-Kan̄̄sa al-atarīya bidair al-qiddīs al- 'az̄im al-anbā Antonios bi'l-baḥr al-aḥmar, Publications of the Monastery of Saint Antony, the Red Sea, 2003, 13, 86. 
small pearls. Contrast between her thick fingers and her heavy legs is visible. Geometric motives colored in black and white in addition to red floral designs appear on her massive seat. The cushion over which she stays is decorated to the left by a band of kuffic inscriptions. Traces of a green color are still visible on her tunic, the napkin covering her head and her cushion. The border of the clipeus is colored in black. The background is gray and perhaps before it was blue. Inside, the Christ blessing and holding codex decorated with a small cross is depicted in frontal attitude with his yellow halo decorated with red cross.

The Deisis or the supplication scene in the monastery of Saint Macarius the Great in Wadi Natrun ${ }^{35}$ is a well known topic in the byzantine and Coptic iconographies (PI. XVI). The busts of the Holy Virgin Mary and John Baptist are seen from profile flanking Jesus Christ the Youth and bending towards him on the eastern part in the octagon of the northern chapel of the main church. The Holy Virgin Mary is to the right of the Christ who is standing in frontal attitude and to his left side Saint John Baptist appears. The Christ is wearing a clear blue tunic and a dark red mantel. His face is surrounded by a big cruciform nimbus colored in yellow and set with a black circle with pearls. Holding a precious rectangular codex and blessing, he is seen with a black hair and his small moustache falling, beard and having hidden feet. The Holy Virgin Mary is shown with a maphorion hug tightly her neck. John Baptist looks like a young man with a red mantel over a yellow tunic, a long hair falling down and decorated with a diadem in addition to his black beard. The artist executed two small roses over the heads of the Holy Virgin Mary and Saint John Baptist perhaps to avoid leaving emptiness. The Holy Virgin Mary is mentioned in this scene by her title Mother of God. The Upper part of the scene is decorated with the figures of the prophets Moses and Aaron. The

${ }^{35}$ J. Leroy, Peintures, 36, pls. 53-55, 59-60; Coptic Art, I, 64-65; G. GABRA, Monasteries, 61, pl. 4.7. 
Deisis scene is differently repeated in the small church of the four leaving creatures in the monastery of Saint Anthony the Great in the Red $\mathrm{Sea}^{36}$. The apse is decorated in two parallel zones. The upper zone shows the Christ Pantokrator haloed and enthroned, holding the holy book and blessing within a mandorla supported by four winged angels. The external large border of the mandorla is decorated with small white stars. A short Coptic inscription is read

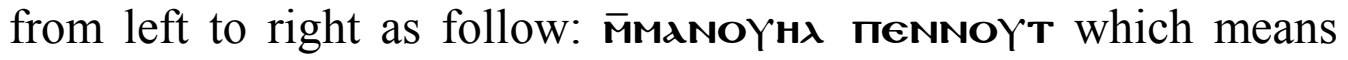
Emmanuel our God. His nimbus is stamped by a cross with other small crosses. His face features reflect the byzantine art influences. The lower section of the apse is depicting the Holy Virgin Mary, John Baptist, the four leaving creatures, the sun and the moon having here human faces. Right to the Christ, the Holy Virgin Mary is standing with two beasts and the sun symbol of the day. To his left side, the artist executed the figures of Saint John Baptist, two other beasts and the moon symbol of the night. Under the scene, there is an Armenian text translated as follow: holy, holy, holy, Lord. In this scene, the Holy Virgin Mary, Saint John Baptist and the four creatures are depicted with their full bodies. Several decorative elements complete the uncommon scene which is richly colored.

The Holy Virgin Mary is also depicted in the decoration of some other Coptic artistic collections which are now conserved in the Coptic Museum in Cairo or in some of the Coptic monasteries. The Crucifixion icon of Jesus Christ ${ }^{37}$ which is painted by two famous artists Ibrahim al-Nasikh and John the Armenian is discovered in several Coptic monasteries and churches (PI. XVII). The Christ is shown hanging on the wood. Below, the Holy Virgin Mary and Mary Magdela are standing crying to the right side and Saint John appears to the other side. The darkness is seen anywhere

\footnotetext{
${ }^{36}$ Coptic Art, I, 91; P. VAN MoORSEL, Peintures, 168-177, fig. 36; G. GABRA, Monasteries, 7879, pl. 6.4; E. S. BOLMAN and P. GODEAU (ED.), Visions, 31, nº3.1; al-Kanīsa al-atarīya, 5859.

${ }^{37}$ Coptic Icons, I, 34-35.
} 
on the icon behind the Christ. Conserved in the Coptic Museum in Cairo, this icon dates back to the $18^{\text {th }}$ century A. D.

One of the most important icons dating from the $18^{\text {th }}$ century A. D. and displayed in the same museum depicts the half figure of the Holy Virgin Mary holding and looking to the Crucifix ${ }^{38}(\mathbf{P I}$. XVIII). Her halo is distinguished by a punched floral element. She is wearing a blue tunic under her purple maphorion. A crown of thorns is on the haloed head of Jesus Christ who has long hair, moustache and beard. His waist is covered by a white loin-cloth. In his hands and feet, wounds are still visible. If anyone looks carefully to the Holy Virgin Mary's face, he will feel that she is very angry and she seems to be crying this event. The faces features reflects the byzantine art influence especially, the long curved eyebrows, the long and thin noses and the small mouths in addition to the brilliant colors. Inscriptions in the golden background of the icon include the title of the Mother of God and the name of Jesus Christ.

In the Lamentation over the Dead of Jesus Christ scene which decorates one of the other icons conserved in the Coptic Museum in Cairo, the Holy Virgin Mary is sitting to the left side and holding her son's head and his shoulders on her knees. Behind her, a woman stretches her hands upwards perhaps she is Mary Magdalene who appears with long brown hair. Both women are wearing a light blue maphorion over a red tunic. In the middle, Jesus Christ with a white loin cloth is lying on the stone of Anointing over which a white shroud is laid. Behind the stone, six men are bending. Most probably, Saint John is holding the left arm of Jesus Christ. At the end of the sarcophagus, Joseph of Arimathea whose hair is long and white holds a part of the shroud. He is also beard and has a moustache. Behind him, Nicodemus bringing his right hand very close to his face holds the ladder with his left hand.

${ }^{38} \mathrm{~N}^{\circ} 3472$. Dimensions: 26,1 x 35,7 x 1,4. Presented by the daughter of Jacob Irshim Pasha. Catalogue, 96-97, $\mathrm{n}^{\circ} 106, \mathrm{pl}$. 26/a. 
Other human faces are partly visible behind Saint John. All these human figures are haloed and wearing tunics with pallia colored in blue, green and red. They have similar features especially the curved eyebrows, the large eyes, the straight noses and the small mouths. All these decorative elements are executed under two brown arcades. The background of the icon is colored in blue, orange and greenish. Dating from the $18^{\text {th }}-19^{\text {th }}$ century A. D., the icon reflects the influence of a provincial Greek artistic style.

In the Dormition or the fall asleep scene of the Holy Virgin Mary ${ }^{39}$, she is lying in the middle and surrounded by the disciples of Jesus Christ. Her haloed head with closed eyes is oriented to the right side. She is wearing a blue tunic covered with purple maphorion decorated with golden gallon and four pearls on the forehead. Her two hands are crossing over her bust. The two Saints Peter and John are near her head and feet. Jesus Christ stands behind then as the byzantine Pantokrator and carries the soul of the Holy Virgin Mary wearing in white as a baby. He has a short bear, fine moustache and his face full of noblesse is surrounded by a cruciferous halo. With a blue tunic and a red mantel, he is flanked y two medallions including winged angels with flabellum. A mandorla supported by other winged angels appears on a blue sky decorated with white stars in the background of the scene.

The Assumption scene of her body especially this example shown now in the Syrian monastery in Wadi Natrun shows the Holy Virgin Mary and the Christ in busts from face and giving hands to each other within garlands. This rare scene partially damaged covers the upper part of the eastern wall of the khurus inside the main church.

In conclusion, various are the representations of the Holy Virgin Mary in Coptic art. The ancient Egyptian iconography was sometimes lying behind some of these images. Such subject is clearly of certain considerable current interest and has special

39 J. LeROY, Peintures, 72-73, pls. 136-146; G. GABRA, Monasteries, 51. 
importance for researchers in Egypt. The different images and various representations of the Mother of God and her several identities as Galaktotrophousa, Gloukaphilousa, Hodegetria, Platytera and Enthroned Regina confirm how she was a model and an ideal woman, mother and saint venerated and respected in both the Bible and the Quran. These different attitudes and expressions are sometimes one of the most difficult problems for students and scholars in Egypt. All these images from the early centuries of Christianity show different events from the biography of the Holy Virgin Mary from the beginning to the end of her life and some details of her clothes, pearls and jewels, her different feelings and face's expressions towards her parents, her Son, her cousin and while being depicted between disciples and saints. When it is time to see her with her Child, they must be flanked by angels and archangels for protection. We cannot forget the evidence of the Coptic artistic style criteria and we cannot omit to mention also the Greek and Byzantine influences in these precious artistic Coptic collections reflecting the power of movement that helped to well understand each attitude. Inscriptions giving her names and titles are associated sometimes with floral and geometric patterns to complete her depiction. As the aim of the present paper was to supply a need which has long been left by those interested in the Egyptian or Coptic Church, I tried as much as I could to provide them with an important overview of the different figures of the Holy Virgin Mary in the Coptic iconography. I hope that researchers and scholars of Coptology and other fields may find something interesting in such study. Perhaps someone else continues searching in this topic to show difference and comparison study of her depiction in East and West especially when she is depicted as Virgin Kykkotissa, Deomene and Virgin of the Passion in Byzantine art in Sinai and in Europe. 


\section{List of Abbreviations and Periodicals}

BIFAO: Bulletin de l'Institut Français d'Archéologie Orientale. (Cairo).

CoptEnc: Coptic Encyclopedia, 8 vols. (New York).

Parole de l'Orient: Parole de l'Orient (Paris). Continue Melto et OrSyr.

SKCO: M. KRAUSE and S. SCHATEN (eds.), QEMELIA. Spätantike und koptische Studien. P. GrossmanN zum 65 Geburtstag (= Sprachen und Kulturen des Christlichen Orients 3), Wiesbaden (1998).

\section{Bibliography}

L'art copte en Égypte 2000 ans de christianisme, exposition présentée à l'institut du monde arabe du 15 mai au 3 septembre et au Musée de l'Éphèse au Cap d'Agde du 30 septembre 2000 au 7 janvier 2001, Institut du monde arabe/Éditions Gallimard, Paris, 2000, (L'art copte 2000).

E. S. Bolman, the Coptic Galaktotrophousa as the Medicine of Immortality, Ph. D. Dissertation, Bryn Mawr College, 1997, (Galaktotrophousa).

E. S. Bolman and P. GodeAu (ED.), Monastic Visions: Wall Paintings from the Monastery of St. Antony at the Red Sea, Yale University Press, Cairo, 2002, (Visions).

Coptic Art. I. Wall Paintings, Text and Photos by Nabil Selim Atalla, Lehnert and Landrock Publisher Cairo, 1993, (Wall Paintings).

Coptic Icons, $1^{\text {st }}$ ed. I-II, Lehnert and Landrock, Cairo, 1998, (Coptic Icons).

M. Cramer, Koptische Buchmalerei; Illuminationen in Manuskripten des christlich-koptischen Ägypten vom 4. bis 19. Jahrhundert, Aurel Bongers, Recklinghausen, 1964, (Buchmalerei).

M.-R. Debergh, "Dayr Apa Jeremiah: Paintings", in A. S. AtiYA (ED.), CoptEnc., III, Macmillan Publishing Company, New York (1991), 777-779, (Dayr).

L. DePuYdT, Catalogue of Coptic Manuscripts in the Pierpont Morgan Library. Album of Photographic Plates, Photographed by DAVID A. LoGGIE, Uitgeverij Peeters, Leuven, 1993, (Catalogue).

The Escape to Egypt according to Coptic tradition, $1^{\text {st }}$ ed., Photos NABIL SELIM AtAlla, Lehnert and Landrock Publisher, Cairo, 1993, (Escape to Egypt).

G. GABrA, Cairo. The Coptic Museum \& Old Churches, with Contributions by A. AlCOCK, Egyptian International Publishing Company-Longman, Cairo, 1999, (Museum).

G. GABRA, Coptic Monasteries. Egypt's Monastic Art and Architecture, With a Historical Overview by T. VIVIAN, AUC Press, Cairo-New York, 2002, (Monateries). 
G. Gabra and M. EATON-Krauss, the Treasures of Coptic Art in the Coptic Museum and Churches of Old Cairo, AUC Press, Cairo-New York, 2006, (Treasures).

The Icons. Catalogue général du musée copte, Published by P. VAN MoORSEL, Mat. ImmerzeEl and L. LAngen, Supreme Council of Antiquities Press, Cairo, 1991, (Catalogue).

Illustrations from Coptic manuscripts, $1^{\text {st }}$ ed., Lehnert and Landrock Publisher, Cairo, 2000, (Coptic manuscripts).

K. C. INNEMÉE, "the Iconographical Program of Paintings in the Church of alAdra in Deir al-Sourian: Some Preliminary Observations", SKCO, III, Wiesbaden (1998), 143-149, (Program).

K. C. INNEMÉE, "New Discoveries at deir al-Sourian, Wadi al-Natrun", SKCO, IV/1, Wiesbaden (1999), 213-219, (Program).

al-Kanīsa al-atarīya bidair al-qiddīs al- 'aẓim al-anbā Antonios bi'l-baḥr alahmar, Publication of Monastery of Saint Antony, the Red Sea, 2003, (Kanīsa).

L. LANGENER, Isis Lactans-Maria Lactans. Untersuchunngen zur koptischen Ikonographie, Oros Verlag, Altenberge, 1996, (Isis).

J. LEROY, Les manuscrits coptes et coptes-arabes illustrés, Librairie Orientaliste Paul Geuthner, Paris, 1974, (Manuscrits).

J. LEROY, "Le programme décoratif de l'église de St. Antoine du désert de la mer rouge", BIFAO, LXXVI, Le Caire (1976), 347-379, (Programme).

J. LeROY, Les peintures des couvents du Ouadi Natroun, publiées avec la collaboration de B. Lentheric, P. H. LAFERriere, H. Studer, E. RaVAult, B. Psiroukis et J. F. GouT, MIFAO 101, Le Caire, 1982, (Peintures).

Magdi Guirguis, Yuhanna al-armānī wa ayqūnātuh al-qibtīya. Fanān fì alqāhira al-Gutmānìya, the Supreme Council of Culture Publication, Cairo, 2008, (Yuhanna).

Th. F. Matheus and N. Muller, "Isis and Mary in Early Icons", in: M. VASSELAKi (Ed.), Images of the Mother of God. Perceptions of the Theotokos in Byzantium, Burlington, 2005, (Isis).

J. QuiBell, Excavations at Saqqara, 1906-1909, Service of Egyptian Antiquities: Institut français d'archéologie orientale, Cairo, (1908-1909, 1912), (Excavations).

L. VAN ROMPAY and K. InNEMÉE, "La présence des syriens dans le Wadi alNatrun", Parole de l'Orient, XXIII, Paris (1998), 167-203, (Présence).

Z. SKalova and G. GABRA, Icons of the Nile Valley, Egyptian International Publishing Company-Longman, Cairo, 2003, (Icons). 
P. VAN MOORSEL, Les peintures murales du monastère de saint Antoine près de la mer rouge, avec des contributions de P. GROSSMANN, K. INNEMEE et P.H. LAFERRIERE et la collaboration de PH. AKERMANN, ABDEL-FATAH Nosseir, B. Psiroukis, K. Crena De IONGH et J. Runierse, MIFAO 112, Le Caire, 1995, (Peintures).

P. VAN MoORSEL, "La grande annonciation de Deir es-Sourian", BIFAO 95, Le Caire (1995), 517-537, (Annonciation).

M. VASSILAKI, Mother of God. Representations of the Virgin in Byzantine Art, Skira, Athens, 2000, (Mother). 


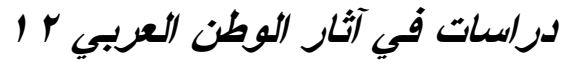

\section{Illustrations}

PI. I

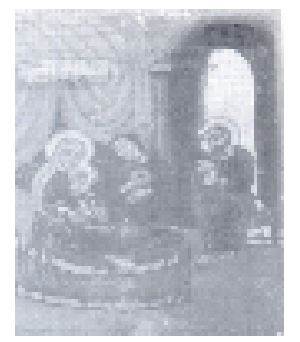

A wooden icon dating from the $18^{\text {th }}$ century A. D. According to Catalogue, pl. 22/b

Pl. II

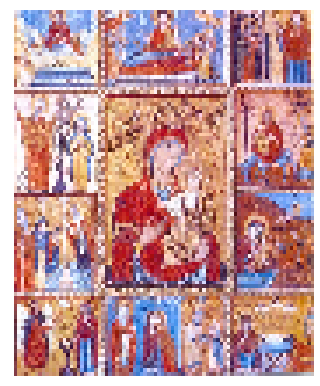

A wooden icon dating from the $18^{\text {th }}$ century A. D. in the Hanging Church of the Holy Virgin Mary in Old Cairo. According to Coptic Icons, I, 73-76.

PL. III

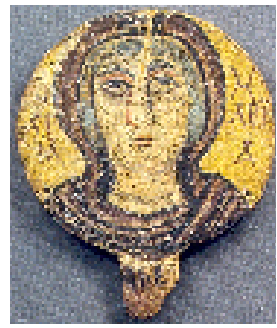

A wooden Tondo from the $6^{\text {th }}$ century A. D. in the Coptic Museum in Cairo. According to Z. SKALOVA and G. GABRA, Icons, $167, \mathrm{n}^{\circ} \mathrm{A}$ 


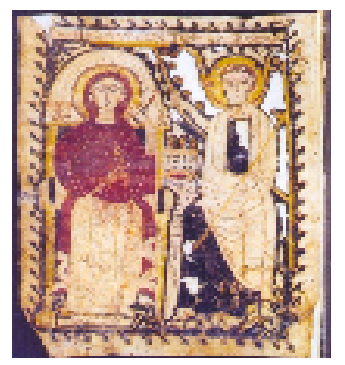

A manuscript dating from the $\mathbf{1 0}^{\text {th }}$ century A. D. the Pierpont Morgan Library at New York. According to J. Leroy, Manuscrits, pl. 35, B

PL. V

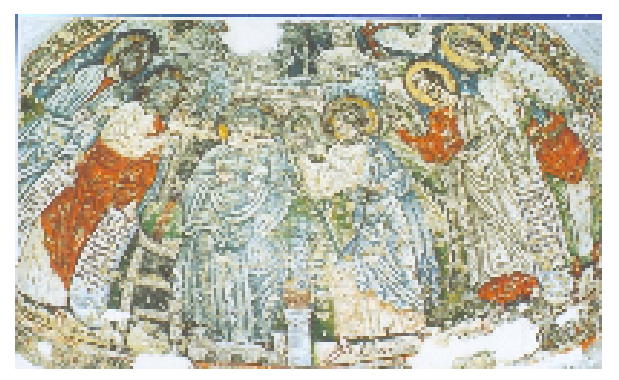

The Coptic Annunciation scene in the Syrians Monastery at Wadi Natrun $\left(7^{\text {th }}-13^{\text {th }}\right.$ century A. D.). According to G. GABRA, Monasteries, pls. 3.8-3.9

PL. VI

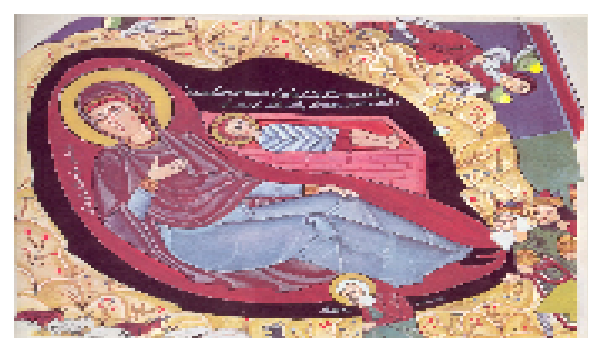

A wall painting in the Syrians Monastery. According to J. LEROY, Couvents. 


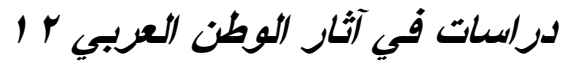

PL. VII

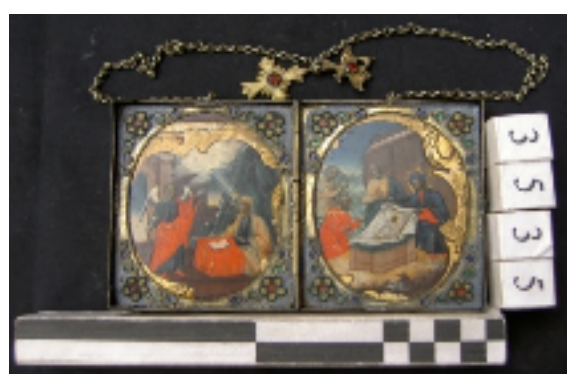

A wooden icon dating back to the $18^{\text {th }}$ century A. D. According to Catalogue, pl. 41/a

PL. VIII

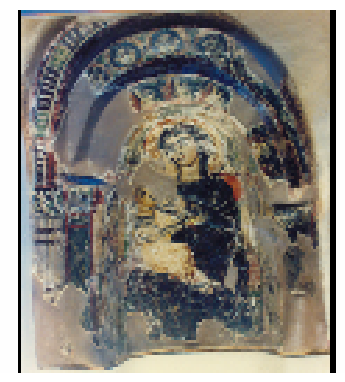

A limestone niche dating to the $6^{\text {th }}$ century A. D. in the Coptic Museum in Cairo. According to Coptic Art, I, 18-19.

PI. IX

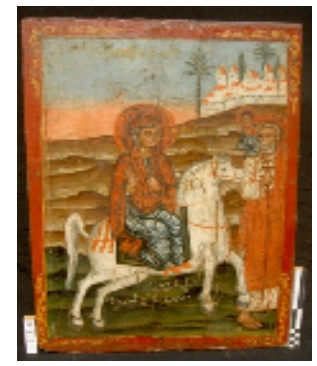

A wooden icon dating from the $18^{\text {th }}$ century A. D. The Coptic Museum in Cairo. According to G. GABRA, Museum, 82, $n^{\circ} 28$ 


\section{دراسات في آثار الوطن العربي بr}

PL. X

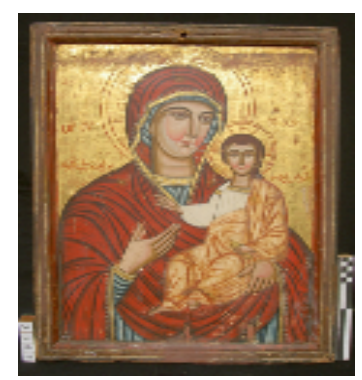

A wooden icon dating from the $18^{\text {th }}$ century A. D. The Coptic Museum in Cairo.

Pl. XI

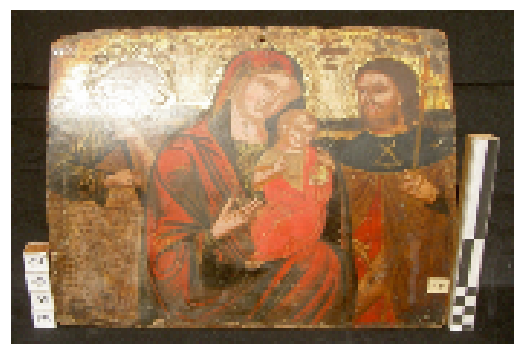

A wooden icon from the $18^{\text {th }}$ century A. D. The Coptic Museum in Cairo. According to Catalogue, $\mathrm{pl}$. 40/b

PL. XII

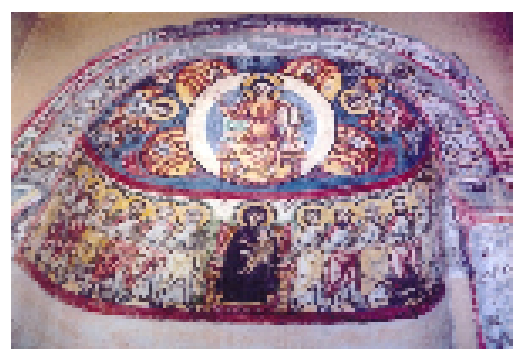

A niche from the monastery of Saint Apollo at Bawit. The Coptic Museum in Cairo, $6^{\text {th }}$ century A. D. According to G. GABRA, Museum, 58-59, $\mathbf{n}^{\circ} 9$ 


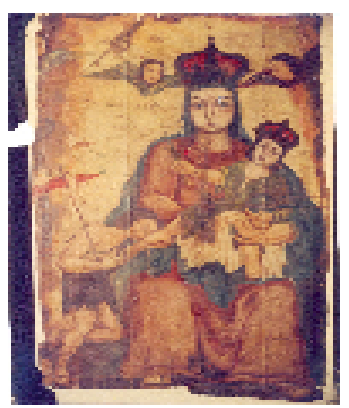

A wooden icon from the $18^{\text {th }}$ century A. D. in the Hanging Church of the Holy Virgin Mary in Old Cairo. According to Escape to Egypt, 34

PL. XIV

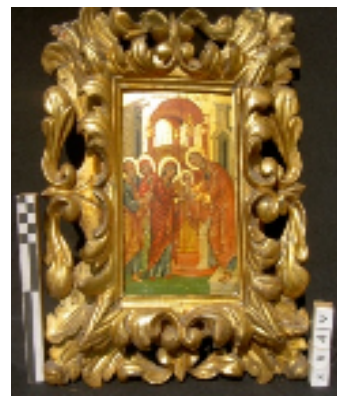

A wooden icon from the $18^{\text {th }}$ century A. D. in the Coptic Museum in Cairo. According to Catalogue, pl. 28/b

\section{PL. XV}

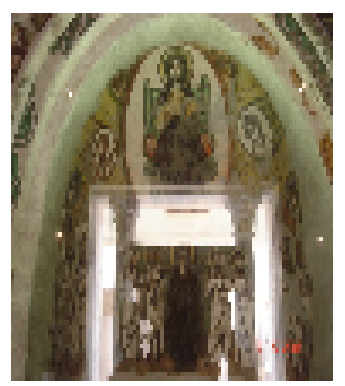

A niche from the $6^{\text {th }}$ century A. D. The Coptic Museum in Cairo 


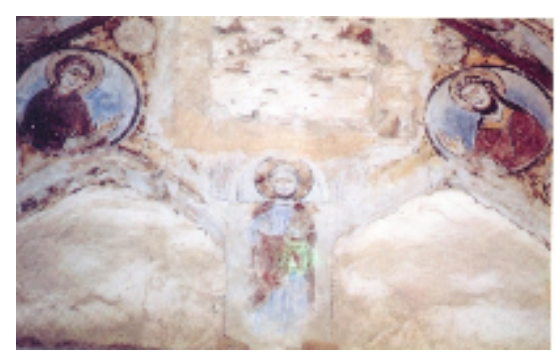

A wall painting in the Monastery of saint Macarius the Great in Wadi Natrun. According to J. LeRoY, Programme, 347-379

\section{PL. XVII}

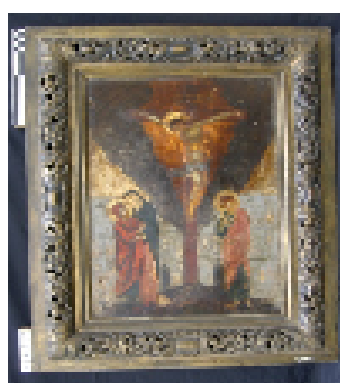

A wooden icon dating from the $18^{\text {th }}$ century A. D. The Coptic Museum in Cairo. According to Coptic Icons, I, 34-35

\section{PI. XVIII}

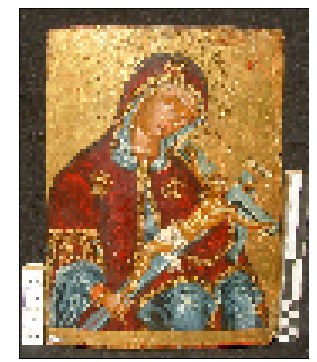

A wooden icon dating from the $18^{\text {th }}$ century A. D. The Coptic Museum in Cairo. According to Catalogue, pl. 26/a 